\title{
The Depreciation of the Continental: A Reply
}

Charles W. Calomiris

There are two ways to interpret Ron Michener's comment on my article. One is to view it as an analysis of the difficulties of estimating money demand and of identifying the relevant components of money supply during the colonial and Revolutionary periods, both of which would be necessary to draw firm conclusions about the time path of aggregate real money balances from 1774 through 1781. Another way to read the comment is as a disproof of the importance of fiscal expectations in determining the market value of the continental. Taking the first view, Michener's contributions and caveats are often well taken, though it was never my intent to estimate (or even describe in detail) the time path for the overall supply or demand for liquidity during this period.

The second interpretation of his comment, which is relevant to the argument of my article, is not warranted by the evidence he presents. Indeed, Michener's comment actually provides some supporting evidence for the importance of fiscal expectations, and does not offer a credible alternative explanation for changes in the silver price of continentals.

It is important to separate the question of the role of expectations from the question of "stable" money demand. In an environment of multiple media of exchange (like the period at issue), the question of the stability of the overall demand for money is essentially unrelated to the question of the determination of the rates of exchange among alternative monies. Michener's discussion of the aggregate real supply of money, which possibly includes several monies and money-like instruments, simply does not bear on the issue of the determination of the exchange rates among each of these instruments. ${ }^{1}$ Michener's central claim, that available data are too poor to allow one to reject the quantity theory for total money balances, is simply beside the point.

My discussion divides into three parts. First, I clarify aspects of my work, and that of others, which Michener misinterprets. Second, I show that Michener's evidence actually supports the importance of fiscal news, and that the quantity theory of aggregate money does not offer an alternative to my (and others') explanation for changes in the value of the continental. Finally, I take issue with Michener's evidence for real balance stability.

\section{QUESTIONS OF INTERPRETATION}

Michener seems to equate uncertain promises of future taxation with unimportant ones. He cites E. James Ferguson to provide evidence against the importance of fiscal

The Journal of Economic History, Vol. XLVIII, No. 3 (Sept. 1988). (C) The Economic History Association. All rights reserved. ISSN 0022-0507.

The author is Assistant Professor of Economics, Northwestern University, Evanston, IL 60201.

${ }^{1}$ For example, during the greenback suspension of 1862 to 1878 real money balances (whether narrowly or broadly defined) maintained a stable relationship with income and interest rates, but the exchange rate (gold value) of greenbacks and the price level fluctuated with fiscal news, while the aggregate nominal money supply adjusted endogenously to the price level. See Wesley C. Mitchell, A History of the Greenbacks (Chicago, 1903); Richard Roll, "Interest Rates and Price Expectations During the Civil War," this Journal 32 (June 1972), pp. 476-98; Gerald R. Thompson, "Expectations and the Greenback Rate, 1862-1878" (Ph.D. dissertation, University of Virginia, 1972); and Charles W. Calomiris, "Price and Exchange Rate Determination During the Greenback Suspension," Oxford Economic Papers (Dec. 1988). 
expectations for the value of the continental. ${ }^{2}$ Here the context, indeed the whole book, from which Michener draws is at odds with his argument. Ferguson's The Power of the Purse is, as the name suggests, a treatise precisely on the importance of fiscal backing for determining the value of currency and other debt. Here Ferguson follows all the other historians of Revolutionary finance cited in my article. When Ferguson describes the backing of continentals as "doubtful" he in no way is arguing that the promised backing was irrelevant. In fact, he is pointing to the increased doubtfulness of the backing as an explanation for the currency's decline. Here is the complete passage from which Michener draws:

Depreciation first began in the summer or fall of 1776, in consequence not only of the volume of emissions, but also the military crisis. As Washington retreated and the British menaced Philadelphia, the faith of the thirteen states pledged to the redemption of Continental money may have seemed a most doubtful guarantee. The decline was registered in higher prices and the rate at which currency exchanged for hard money. ${ }^{3}$

This is precisely the explanation I adopted for the initial stage of the decline in the currency's value. Ferguson, like every other historian of Revolutionary finance, emphasizes the central role of fiscal expectations in determining the currency's value. The novelty in my article was mainly the use of a formal model which describes two alternatively binding constraints on real continental balances. When expected backing is sufficiently high, nominal money issues act as the binding constraint; when expected backing is low, marginal changes in expected backing affect real balances. This is a useful framework for understanding the lack of any simple observed relation between currency emissions and the exchange rate.

As I pointed out in my article, historians based this view on the accounts of contemporaries. In his letter to Francisco Rendon of March 5, 1782, Gouverneur Morris describes the influence of fiscal news on the value of the currency and emphasizes the failure of state tax backing and the Forty-for-one Act as the principle sources of bad news from 1780 on:

Among all the operations of government that of taxation requires the greatest time and attention . . . But in a country like this, where the people are their own rulers, the obstacles to it are most insurmountable . . . As taxes were not laid to fund the paper money, it soon depreciated, from that circumstance, and the excessive quantity which was issued to answer the exigencies of the service. But it is worthy of notice that this depreciation was very little accelerated or retarded by good or evil fortune. The losses in the campaign of 1776 did not impeach the credit or impair the value of the paper, and the successes which crowned the end of that and the beginning of the next year did not prevent a depreciation, which became sensible in the spring of 1777 . This depreciation proceeded regularly and with increasing rapidity thro that year, and after the capture of Burgoyne on one hand, and the loss of Philadelphia on the other, the treaty with France was announced at York town in the spring 1778, the money then being at about four to one. The evacuation of Philadelphia and the revival of commerce in consequence of that and of the french fleet kept the money at about five for one, untill the autumn of that year. The depreciation still went on, but was arrested in its course by a hope of peace from the mediation of Spain; because it was supposed that in peace the value would be restored. When this hope subsided, and the temporary influence of it ceased, the depreciation became more rapid; and then the Congress, in order to lessen the quantity of money and prevent the mischiefs arising from some counterfeits, called in a considerable sum to be loaned. This step, which they expected would prevent depreciation, greatly increased it. The confidence of the people was shaken, and could not be restored. The paper went fast to ruin, and in the spring 1780 it was determined to call it all in, and issue new paper at a value of one for forty of the old, which new paper was to bear interest at five percent. This measure has given rise to so many different opinions and speculations both in Europe and America that it is not necessary to

${ }^{2}$ E. James Ferguson, The Power of the Purse: A History of American Public Finance, 1776-1790 (Chapel Hill, 1961).

${ }^{3}$ Ibid., p. 31. 
examine it at large, but one or two observations may not be amiss. The moment when former promises are demonstrated to be fallacious, is not the moment to make new promises. The strict connections between the new paper and the old injured it, because the depreciation of the old from forty to eighty, necessaryly brought down the new to two for one. The expectation [on the part of Congress] that taxes would prevent this mischief was ill founded, because the taxes were fixed in paper. . . 4

Gouverneur Morris argues that the quantity of money issued was not by itself the determinant of its value; rather, the quantity issued (and expected to be issued) relative to expected future tax backing acted as the main influence on the value of currency.

Michener's discussion of the Forty-for-one Act is at odds with Morris's, and my, discussion of the Act. Michener claims that "one would expect that continental currency should have depreciated abruptly in March 1780"' (p. 685)." Finding no abrupt depreciation in the data for April of 1780, he argues that the fiscal backing theory fails. Michener does not mention the large depreciation (from 45.25 continentals per specie dollar to 61.50) for the average value in February to that of March 1780. According to the backing view, the timing of exchange rate changes should correspond to the timing of the news of Congress' intent. Thus my description, and Gouverneur Morris's, are fully consistent with the large depreciation that occurred immediately prior to the enactment of the Forty-for-one Act.

The version of my exchange-rate model which Michener claims to "test" and reject is a straw man which I did not propose. In the appendix to my article, I began with the simplest model of money demand in which government-supplied paper had no substitutes and derived the implication that the level of real money balances is inversely related to expected inflation, holding income, wealth, and real interest rates constant. Michener adopts this model and rejects the fiscal backing view based on the lack of correlation between real balances of continentals and actual rates of inflation.

Michener's test is flawed for several reasons: First, the initial heuristic model was qualified in an important respect which Michener ignores. I stated explicitly that the availability of substitutes for continentals would not change the basic result of the model (the link between fiscal news and the exchange rate) but would dampen and perhaps eliminate the supposed correlation between real balances and expected inflation:

A novel feature of this case is that total real money balances . . . are bounded from below by the zero-inflation level of money demand. Government liquidity rent (or seignorage) is limited due to the availability of an elastically supplied . . . substitute . . . which maintains its real value in specie terms (p. 67).

Here I point out that the existence of substitutes like coin, state-issued paper, or trade credit, may place an upper bound on equilibrium expected inflation. This is perfectly compatible with viewing actual inflation as mainly unanticipated changes in the price level due to fiscal news. In this case real continental balances and expected inflation may be uncorrelated.

A second problem of Michener's test is that variation in income, wealth, and real interest rates is not accounted for. If these variables are correlated with changes in inflation or money issues, then Michener's results will be biased. Finally, actual inflation is a poor indicator of expected inflation in an environment in which unanticipated fiscal news is an important determinant of the exchange rate and price level.

\section{QUESTIONS OF LOGIC}

The claim that the quantity theory can offer a substitute explanation for the fiscal-backing view of continental depreciation is simply fallacious. To see this, consider

${ }^{4}$ See John Catanzariti and E. James Ferguson, eds., The Papers of Robert Morris (Pittsburgh, 1984), vol. 4, pp. 353-54. 
a simple money-demand function in which the aggregate level of real balances is constant (equal to $X$ in commodity units), and in which money consists of the components Michener suggests: continentals $(C)$, specie $(S)$, state issues $(I)$, and book credit $(B)$. The assumption of a constant level of real money balances enables one to make the argument $a$ fortiori, and amounts to abstracting from changes in income and wealth effects in money demand.

Define $e_{c}$ and $e_{i}$ as exchange prices, denominated in specie, of continentals and state currency issues respectively. Book credit, indexed to inflation, is assumed to be denominated effectively in units of specie. Define a commodity price index, denominated in specie, as $e_{p}$. This strict version of the quantity theory yields the following expression:

$$
e_{p} X=e_{c} C+e_{i} I+S+B .
$$

This condition is not sufficient to determine $e_{i}$ or $e_{c}$. To demonstrate this argument $a$ fortiori, assume that $e_{p}$ is primarily determined by international price parity or given domestic commodity and specie supplies, and that $I$ and $C$ are given by exogenous policy. There remain an infinite number of combinations of $e_{c}$ and $e_{i}$ which satisfy this equation. In fact, there would still exist an infinite number of equilibrium combinations of the two exchange rates even if $S$ and $B$ both were assumed to be pre-determined for all time. Of course, the supplies of specie and book credit were not set exogenously; rather, they rose and fell (when not otherwise constrained) to offset movements in the real supply of their close substitute, paper currency.

Fiscal (redemption) expectations tie down the time paths for $e_{c}$ and $e_{i}$, and explain the movements over time in the relative prices of continentals, state note issues, and specie, as I described in my article. Absent additional constraints like these, it is not possible to explain exchange rates among monies or long-run specie flows. The assumptions of substitutability among monies and an aggregate quantity theory of money demand simply cannot provide explanations for the changing exchange values of the continental or the state issues, or for the changing composition of real balances.

Michener does not address the problem of relative price determination among monies. He does erroneously suggest, in one curious passage, that Congress (or someone) initially maintained exchange-rate parity for the continental. ${ }^{5} \mathrm{He}$ occasionally invokes Gresham's Law to eliminate one or another premium medium of exchange from the aggregate money-demand function. This, of course, already presumes a mechanism for determining relative currency prices, which Michener's story lacks. Moreover, it presumes that currencies that become less used for trading are not potentially useful for

${ }^{5}$ It is hard to imagine what Michener has in mind when he writes: "continental currency initially circulated at par with specie. As issues multiplied in 1775/76, specie disappeared from circulation. With the displacement of specie, the par of exchange could no longer be maintained, and the continental began to float against other currencies (p. 683)." When a government pegs the exchange rate between its currency and specie by promising convertibility upon demand, then depletions of the government's supply of specie can, as this passage suggests, make it impossible to maintain parity. The Continental Congress, however, never pegged continental-specie exchange rates in this way, and never hoarded specie to ensure future convertibility. Thus, there was no connection between specie flows out of the country and government backing of the currency. It is beyond the scope of this reply to challenge more generally Michener's "customary fixed-exchangerate" view of colonial currency valuation. See Bruce D. Smith, "Money and Inflation in the American Colonies: Further Evidence on the Failure of the Quantity Theory" (unpublished manuscript, University of Western Ontario, 1987); and fn. 38 of my article. Parities in tax collection between paper currency, on the one hand, and specie or commodities, on the other hand, in some cases acted to "fix" exchange rates, though this is not the mechanism which Michener imagines. Examples of the operation of this mechanism are available upon request. 
trading and should not be included in the definition of money. Before continentals were issued, specie and colonial bills performed dual functions as stores of value and media of exchange. With the onset of war, specie and colonial bills became the superior stores of value (they were more immune to the changing fortunes of the Revolutionary War), while continentals became a more convenient medium of exchange (probably because prices were usually quoted in continentals and their use avoided haggling over a rate of exchange). Commodity transactions continued to occur in both continentals and specie, and individuals exchanged one medium for the other as well (hence, the data on exchange rates). To suggest that premium currencies should be excluded from the measure of the money supply is to neglect the store-of-value function which specie had served before the War, and to underestimate the transactability of specie during the War. Finally, Michener's advocacy of Gresham's Law is not consistent. Sometimes (when it suits his purpose as quantity-theory advocate) he includes multiple currencies trading at varying exchange rates in his definition of the money supply. To summarize, Michener fails to provide an explanation for which media depreciate in relative terms, or for the conditions under which a premium currency will be driven from circulation, and neglects the store-of-value function of money in his treatment of money demand. ${ }^{6}$

Michener's discussion of the new-tenor note issues and other increases in federal debt in 1780 and 1781 , which coincided with continental depreciation, only provides further evidence of the importance of fiscal backing. For a given level of expected real tax resources, an increase in federal debt will make currency redemption less likely. This is especially true if, as I argued (p. 64), it made sense for the public to anticipate that these debt issues would be favored over currency by future redemption policy. It is important to note that while the continental suffered continued depreciation in the face of these federal debt issues, Pennsylvania currency retained its specie value, as I showed in my article. This change in relative paper currency prices is fully consistent with the tax-backing view and not explicable by appeal to the quantity theory.

\section{QUESTIONS OF MEASUREMENT}

Although the question of the definition and time path of aggregate real money balances is tangential to the question of exchange-rate determination, Michener's description warrants some discussion. His selective inclusion of state issues (excluded in 1776 but included in 1780), interest-bearing notes (excluded when issued by states, included when issued by the Congress in the form of new-tenor notes and certificates in $1780 / 81$ ), specie (excluded in 1776, and included in 1780), and book credit (included as needed to counter movements in the remaining components of money) is very selective indeed. His discussion seems designed to answer the question: "If one wanted to believe that aggregate real money balances had never changed, what else would one need to believe." Thus he is not concerned by the lack of data on new-tenor emissions or state-issue exchange rates; his goal is simply to show that one can believe in the

\footnotetext{
${ }^{6}$ History is full of examples which contradict Gresham's supposed "law." Currencies often have circulated at a premium alongside those of lesser market value and equal face value. See Angela Redish, "Why Was Specie Scarce in Colonial Economies? An Analysis of the Canadian Currency, 1796-1830," this Journal, 44 (Sept. 1984), p. $7 \rightarrow$ Arthur J. Rolnick and Warren E. Weber, “Gresham's Law or Gresham's Fallacy?," Journal of Political Economy, 94 (Feb. 1986), pp. 185-99; David Martin, "The Changing Role of Foreign Money in the United States, 1782-1857," this JournaL, 37 (Dec. 1977), pp. 1009-27; and Charles W. Calomiris, “Explaining Gresham's Law" (unpublished manuscript, Northwestern University, 1986). Michener argues that legal tender laws may have driven specie from circulation, but available evidence indicates that price controls were not enforced. See Albert Bolles, Financial History of the United States, 1774-1789 (New York, 1883), pp. 158-89. Furthermore, continentals were driven out of circulation by mid-1781, a clear contradiction of Gresham's Law.
} 
constancy of real money balances if one is willing to be flexible about the definition of money. What a surprise.

At the same time, Michener's discussion of the increased demand for money and reduced usefulness of book credit during the War is well taken, and no doubt explains some of the increase in real money stock. His two-month lag correction for exchange rates prior to 1780 , and his revision of continental money issues in 1779 are also well taken, though they are of little consequence for the time path of real continental money balances.

Michener's use of Bezanson's price index to deflate nominal continentals is more suspect. I was interested in measuring the changing expectations of specie (that is, tax) redemption, hence my use of specie exchange rates rather than commodity prices. The use of a commodity price index is generally more appropriate for Michener's purpose (estimating aggregate real money demand) under standard assumptions. But commodity price parity across the colonies may have been poor relative to specie price parity, because of relative ease of specie transport. Thus the exchange rate series may be a better indicator of national prices than the commodity price index in Philadelphia.

\section{CONCLUSION}

Economic theory can illuminate history or obscure it depending on the motivations which give rise to the application of theory. If history is used as a wheel on which to grind time-invariant propositions like the quantity theory, and if evidence is used and sources are interpreted selectively to support such propositions, little will be learned. Economists can further historical understanding most by bringing tools rather than conclusions to the arena of historical debate. 